\title{
Perspective: Mitochondria-ER Contacts in Metabolic Cellular Stress Assessed by Microscopy
}

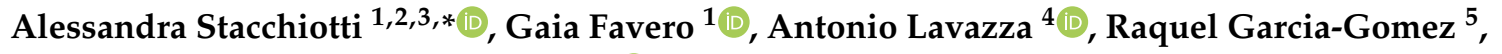 \\ Maria Monsalve ${ }^{5}$ and Rita Rezzani ${ }^{1,2}$ (D) \\ 1 Anatomy and Physiopathology Division, Department of Clinical and Experimental Sciences, University of \\ Brescia, Viale Europa 11, 25123 Brescia, Italy; gaia.favero@unibs.it (G.F.); rita.rezzani@unibs.it (R.R.) \\ 2 Interdipartimental University Center of Research "Adaptation and Regeneration of Tissues and \\ Organs-(ARTO)", University of Brescia, 25123 Brescia, Italy \\ 3 ANZAC Research Institute, Concord Hospital, NSW 2139 Sydney, Australia \\ 4 Istituto Zooprofilattico Sperimentale della Lombardia ed Emilia Romagna-IZSLER, 25124 Brescia, Italy; \\ antonio.lavazza@izsler.it \\ 5 Instituto de Investigaciones Biomedicas “Alberto Sols” (CSIC-UAM), 28029 Madrid, Spain; \\ rgarcia@iib.uam.es (R.G.-G.); mpmonsalve@iib.uam.es (M.M.) \\ * Correspondence: alessandra.stacchiotti@unibs.it; Tel.: +39-030-3717478
}

Received: 12 November 2018; Accepted: 19 December 2018; Published: 21 December 2018

\begin{abstract}
The interplay of mitochondria with the endoplasmic reticulum and their connections, called mitochondria-ER contacts (MERCs) or mitochondria-associated ER membranes (MAMs), are crucial hubs in cellular stress. These sites are essential for the passage of calcium ions, reactive oxygen species delivery, the sorting of lipids in whole-body metabolism. In this perspective article, we focus on microscopic evidences of the pivotal role of MERCs/MAMs and their changes in metabolic diseases, like obesity, diabetes, and neurodegeneration.
\end{abstract}

Keywords: mitochondria; endoplasmic reticulum; MERCs; MAMs; obesity; neurodegenerative diseases; microscopy

\section{1. "Contactology" a New Branch of Cytology}

"Contactology" is a recent term proposed by Csordas et al. [1] to indicate the study of the physical and functional bridge between mitochondria and endoplasmic reticulum (ER), and it represents a sort of "synapse" that drives cellular physiology. The nanometric distance that separates endoplasmic reticulum tubules and the outer mitochondrial membrane is a dynamic essential passage of lipids, glycogen, and calcium ions essential for cellular activity and disrupted in diseases [2-6]. Despite recent in-depth authoritative reviews on its molecular biology and biochemistry $[7,8]$, the detailed visualization of this close connection is still a challenge. Multiple microscopic methods are required to best characterize this structure at the nanometric level and to quantify the membrane contacts in different experimental and pathological conditions. This perspective article intends to provide researchers with an updated insight on imaging of the interplay between mitochondria and the ER in metabolic stress, like diabetes and obesity, and in neurodegenerative diseases.

The use of microscopy to visualize the spatial arrangements of eukaryotic cells and their subcellular organelles is a fundamental tool for acquiring biological and medical knowledge. Here, we provide a brief history of the significant milestones that have contributed to our present day understanding of mitochondria and the endoplasmic reticulum (ER). This timeline is closely associated with the evolution of microscopy. The word "mitochondria" was first used at the end of the nineteenth century by Carl Benda, a German microbiologist, who observed filamentous structures inside cells that 
were stained by crystal violet under a simple light microscope. In the 1950s, mitochondrial morphology and oxidative function became clearly defined [9,10]. In 1953, ultrastructural images of mitochondria were published independently by Sjostrand [11] and Palade [12]. In these seminal manuscripts, the authors characterized the outer and inner membranes and defined "cristae" as the arrangements in the matrix. More recently, high voltage electron microscopes and computerized reconstruction of tilt series images have led to the three-dimensional (3D) visualization of mitochondria $[13,14]$. Using electron tomography, we can now appreciate cristae junctions, a sub-compartment of mitochondrial cristae that are involved in the exchange of lipid and proteins and their alterations in diseases [15]. It has been shown that mitochondrial cristae are affected in neurological diseases like Alzheimer's and Parkinson's or amyotrophic lateral sclerosis [16-18]. Moreover, the dogma that each cell has a fixed number of cristae in its mitochondria has been recently challenged. Further to this, the leg muscles of athletes with long term endurance training display a higher number of cristae in mitochondria, in contrast to sedentary subjects, which might contribute to an increase in performance [19]. Recent work has shown that cristae morphology is coupled with higher oxidative phosphorylation and that increased cristae appear to create more surface area for adenosine triphosphate (ATP) synthesis [20]. Abnormal cristae and smaller mitochondria have been observed during apoptosis, when cytochrome $\mathrm{c}$ is released from mitochondria into the cytoplasm [21]. Further, the shape and localization of mitochondria differ by cell type. For example, in cardiomyocytes, there are different populations of mitochondria localized at the subsarcolemmal and intermyofibrillar area [22], whereas in renal proximal tubular cells the mitochondria appear to be predominantly elongated [23] and neurons display a heterogeneous distribution of mitochondria that appear to be linked to calcium flux [24]. Mitochondria shape and dimensions are known to adapt and shift greatly under metabolic stress conditions, like oxidative damage, hypoxia, and glycemic changes $[25,26]$. "Fusion" is the process that produces elongated or tubular mitochondria, whereas "fission" is the shortening process, and, interestingly, both processes may occur in the same mitochondrion under different metabolic states [27]. Recently, it has been shown that mild upregulation of the protein optic atrophy 1 (OPA 1) in the inner mitochondrial membrane reversed metabolic stress and apoptosis and ameliorated cristae number in fibroblasts and hepatocytes [28].

Another important discovery in the history of microscopy was made by Palade, a Romanian biologist, who visualized electron-dense particles that are associated with endoplasmic cisternae, known at that time as "Palade particles", but known now as ribosomes [29]. Palade was awarded the Nobel Prize in Physiology and Medicine in 1974 for his work describing the smooth (SER) and rough endoplasmic reticulum (RER) membranes with or without ribosomes [30]. To date, the ER, as defined by modern imaging techniques, is known to be composed of perinuclear sheets (RER) and peripheral tubules (SER) that are localized to different cytoplasmic compartments [31,32]. In COS-7 cells the ER subdomains, called organized smooth endothelial reticulum (OSER), have been visualized by ultra-microscopy [33]. Similar features have been detected in neurons that were taken from patients with amyotrophic lateral sclerosis [34]. Three-dimensional imaging has further characterized the shape and extent of ER in mammalian cells and demonstrated the importance of ER morphology and its involvement in processes, like calcium flux, unfolded protein response, and cell death $[35,36]$.

The dynamic nature of mitochondria and the ER has led scientists to consider the alternative hypothesis of a cytoplasmic environment as one of the non-static interconnected organelles [37-39]. Csordas et al. [40] demonstrated, by electron microscopy, the close proximity between mitochondria and ER and then calculated that this distance corresponded to $25-40 \mathrm{~nm}$ for RER-mitochondria and $10 \mathrm{~nm}$ for SER-mitochondria. Examples of juxtaposition, without the loss of organelle integrity, of the outer mitochondrial membrane and ER were shown in this seminal work [41], and interestingly, ER enclosing mitochondria in specific sites contributed to their fission [42].

The nomenclature of the peculiar arrangement between mitochondria and ER is often confused due to the different techniques adopted in various laboratories to study these components. Thus, in mammalian cells, mitochondria-ER juxtaposition was defined as mitochondria-ER contacts 
(MERCs) [43] or membrane contact sites (MCSs) [44], but also mitochondria-associated ER membranes (MAMs), [45-47]; while in mutant yeast, the same observation is known as a ER-mitochondria encounter structure (ERMES) [48,49].

\section{Imaging of Mitochondria-ER Interface by Electron Microscopy}

The exchange of lipids is essential for the maintenance of mitochondrial membranes and it is driven at the ER-mitochondria juxtaposition [50]. In particular, sterols, such as phosphatidylserine and phosphatidylcholine that are produced in the ER, are transported into mitochondria [51]. Recent studies demonstrated that a reduction in phosphatidylethanolamine (PE) in PSB-2 cells, a mutant CHO cell line, induced abnormal MAMs and led to aberrant mitochondrial fragmentation [52]. Moreover, in cells, PE is anchored to autophagosomes in a process called lipidation and this anchor is necessary for efficient autophagy [53]. Remarkably, as observed by conventional and immunogold electron microscopy, autophagosomes were also produced at MAMs in starved COS-7 cells [54].

In HT1080 fibrosarcoma cells, the distance between SER-mitochondria and RER-mitochondria is $8 \mathrm{~nm}$ and $50-60 \mathrm{~nm}$, respectively [55]. In mice liver that was analyzed under cryo-electron microscopy and tomography, MERCs/MAMs length and thickness changed upon metabolic energy intake, i.e., increased under starvation but decreased in over-nutrition [43,56]. It has been estimated that, in mammalian cells, about $20 \%$ of the mitochondria surface is attached to the ER membranes [57]. Moreover, during early phases of ER stress response, HeLa cells that were treated with tunicamycin enhanced the ER-mitochondria contacts to sustain mitochondrial metabolic activity [58]. Arruda et al. [59] demonstrated enriched MAMs in the liver of leptin-deficient mice and in dietary induced obese mice. This finding was related to an excessive calcium flux from the ER to mitochondria and consequent apoptosis. Our research group reported that melatonin supplementation restored the enlargement of MAMs distance in leptin deficient mice liver as compared to its abnormal narrowing in obese mice [60]. This gap was evident in C57BL6/J mice liver, but decreased in leptin deficient mice, together with ER fragmentation and altered mitochondria (Figure 1A,B). Moreover, caloric restriction of transgenic mice that are heterozygous for sirtuin 1, a class III histone deacetylase crucial for mitochondrial health [61], led to excessive MAMs contacts in hepatocytes when compared to wild type mice (Figure 1C,D). The maintenance of a regular MAMs distance was critical for insulin signaling and affected insulin resistance [62]. Indeed, in cyclophilin D KO mice liver, the absence of this mitochondrial protein resident in the MAM interface blocked insulin flux and its local response. Disrupted MAMs have also been characterized in neurodegenerative disorders, including Alzheimer's and Parkinson's disease [63].

Furthermore, among the powerful imaging techniques of the brain, we must consider scanning electron microscopy, which is able to provide multiple $3 \mathrm{D}$ reconstructions of membrane contact sites in neurons by a focused ion beam [64]. 


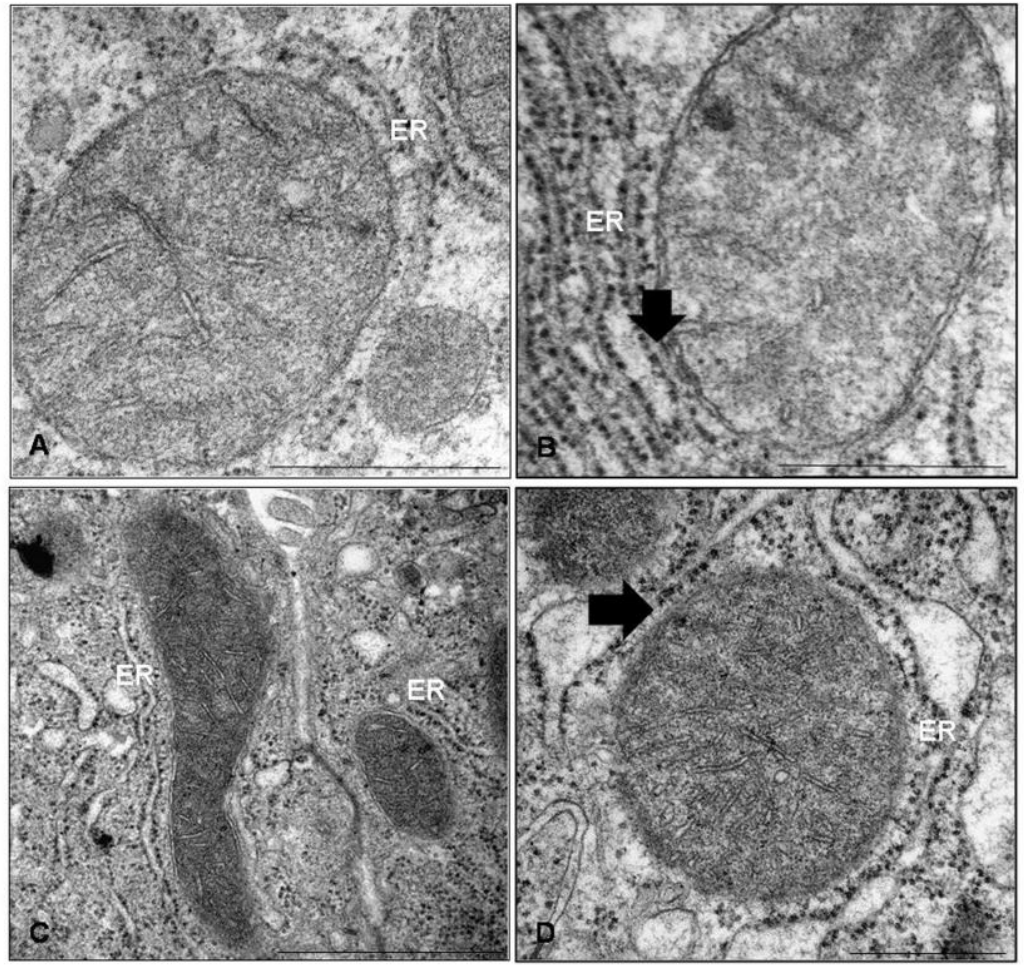

Figure 1. Mitochondria-associated endoplasmic reticulum membranes (MAMs) ultrastructure in adult mice liver changed with nutrition. (A) C57BL6/J mice liver fed a maintenance diet; (B) leptin-deficient obese mice presented abnormal endoplasmic reticulum (ER) cisternae and narrowing of contacts; (C) repeated starved C57BL6/J mice showed regular distance and elongated mitochondria; (D) repeated starved sirtuin 1 heterozygous mice presented close ER-mitochondria contact and swollen cisternae. (ER): Endoplasmic reticulum; arrows identify MAM narrowing. Scale bar: A, B, D 500 nm; C $1 \mu \mathrm{m}$.

\section{Imaging of Mitochondria-ER Interface by Dynamic Fluorescent Light Microscopy}

The major drawback of electron microscopy is the necessity of fixation that makes it impossible to follow dynamic events. Moreover, the nanometric distance between outer mitochondrial membrane and ER represents a challenge for conventional optical microscopy, because it is below the resolution limit. Currently, confocal and super resolution microscopy are overcoming these limitations and allowing the visualization of MAMs and calcium flux using fluorescent probes [65]. New methods, like time lapse microscopy and soft-x-ray tomography, have further characterized the 3D structure of MAMs in COS-7 cells [66]. To verify the role and dynamics of MAM resident proteins in vivo, different interesting methods have been developed based on green fluorescent protein (GFP) or Venus yellow fluorescent protein (YP) probes and confocal laser or super-resolution microscopy. One method, called the dimerization dependent assay, employed non-fluorescent monomers; one that was located on the ER and the other on the mitochondrial side of MAMs, which dimerized and became fluorescent when their distance decreased under 10-20 nm [67]. Another confocal technique, called fluorescence resonance energy transfer (FRET) based indicator of ER-mitochondria proximity, followed calcium flux in MAMs in mutated mouse fibroblasts using donor and acceptor probes to produce fluorescence at nanoscale level [68]. Total internal reflection fluorescence (TIRF) microscopy, which is based on a high power laser light, has been successfully used to image the phosphatidylserine (PE) transfer from ER to mitochondria in live HeLa cells in an aqueous medium with lower refractive index [69]. A recent GFP-based fluorescent technique that was developed by Cieri et al. [70] firstly indicated that, in HeLa and HEK293 cells, there were different types of short $(8-10 \mathrm{~nm})$ and long $(40-50 \mathrm{~nm})$ tethers between mitochondria and ER that responded differently to pharmacological stimuli and starvation. To best detect dynamic changes to MAMs in the liver induced by stressors, like glucose or apoptotic 
inducers, many laboratories have adopted a powerful fluorescent technique, called "proximity ligation assay" [71]. Using this method and fluorescent analysis of calcium transport, Rieusset et al. [72] have demonstrated that abnormal MAMs and disrupted calcium signaling greatly contributed to insulin resistance in hepatocytes in cyclophilin D knockout mice. Super-resolution microscopy now provides scientists with the ability to follow single fluorescent molecules and their trajectories in the ER in neurons and how their flux is perturbed in neurodegenerative conditions [73,74].

These technological advances now make it feasible to examine the role of MAMs connections in the development of neurodegenerative disease and provide tools for examining whether the reversal of these changes may be harnessed for therapeutic purposes. Synthetic linkers have been successfully tested to restore regular MAMs in metabolically stressed hepatocytes [59] and the overexpression of the neuronal calcium sensor 1, a resident linker, in fibroblasts of the Wolfram syndrome patients restored MAMs and proper calcium transfer to mitochondria [75]. Further refinement of our knowledge through microscopy has provided opportunities to translate these preliminary results into clinical applications.

In conclusion, there is no preferred method to visualize MAMs/MERCs/MCSs in cells and every microscopy technique has advantages and disadvantages that must be considered.

In our opinion, the best approach is to combine different methods. In Table 1, the advantages and disadvantages of MAMs/MERCs/MCSs imaging are summarized.

Table 1. MAMs/mitochondria-ER contacts (MERCs)/membrane contact sites (MCSs) imaging in cells.

\begin{tabular}{ccc}
\hline Microscopy/Methods [References] & Advantages & Disadvantages \\
\hline $\begin{array}{c}\text { Transmission Electron Microscopy-TEM } \\
{[40-42,59,60]}\end{array}$ & Elective for nanoscale resolution & $\begin{array}{c}\text { Not suitable for living cells } \\
\text { Technically hard } \\
\text { Expensive }\end{array}$ \\
\hline Cryo-TEM plus tomography [43] & 3D images in small volumes & Not suitable for living cells \\
\hline Scanning Electron Microscopy-SEM FIB & $\begin{array}{c}\text { Good resolution 3D images in } \\
\text { large volumes }\end{array}$ & Not suitable for living cells \\
\hline Confocal Laser Fluorescence & $\begin{array}{c}\text { Suitable for living cells and } \\
\text { dynamic events } \\
\text { Quantification contacts }\end{array}$ & $\begin{array}{c}\text { Toxic for cells after long time } \\
\text { Lower Resolution } \\
\text { Unstable }\end{array}$ \\
Microscopy [41,48,49,52,56,62,66,70-72] & Specific probes required \\
\hline Total Internal Reflection Fluorescence & High Brightness \\
Microscopy [69] & Suitable for dynamic events & $\begin{array}{c}\text { Sensitive to refraction index } \\
\text { Thermogenic }\end{array}$ \\
\hline Super-resolution Microscopy [67,73,74] & $\begin{array}{c}\text { High Brightness } \\
\text { 3D images } \\
\text { Quantification contacts }\end{array}$ & $\begin{array}{c}\text { Specific probes required } \\
\text { Expensive }\end{array}$ \\
\hline
\end{tabular}

Author Contributions: Conceptualization and writing, A.S.; original draft preparation and editing, G.F.; sirtuin 1 heterozygous mice treatment, R.G.-G.; funding, A.S., M.M. and R.R.; electron micrographs, A.L.; supervision, R.R. All authors approved the revised version.

Funding: This research was funded by FFARB 2017 of A.S., ex $60 \%$ grants of University of Brescia (Italy) of A.S. and R.R. and Spanish "Ministerio de Economía Industria y Competitividad" (MINEICO) that includes FEDER funds (SAF2015-63904-R) and from the European Union's Horizon 2020 research and innovation program under the Marie Skłodowska-Curie agreement 721236-TREATMENT of M.M.

Acknowledgments: Authors thank Victoria Cogger for her critical revision of the English text and Alessandra Warren for final editing and proofing.

Conflicts of Interest: The authors declare no conflict of interest. The funders had no role in the design of the study; in the collection, analyses, or interpretation of data; in the writing of the manuscript, or in the decision to publish the results. 


\section{References}

1. Csordas, G.; Weaver, D.; Hajnoczky, G. Endoplasmic reticulum-mitochondrial contactology: Structure and signaling functions. Trends Cell Biol. 2018, 28, 523-540. [CrossRef]

2. Simmens, T.; Herrera-Cruz, M. Plastic mitochondria-endoplasmic reticulum (ER) contacts use chaperones and tethers to mould their structure and signalling. Curr. Opin. Cell Biol. 2018, 53, 61-69. [CrossRef] [PubMed]

3. Area-Gomez, E.; Schon, E. On the pathogenesis of Alzheimer's disease: The MAM hypothesis. FASEB J. 2017, 31, 864-867. [CrossRef] [PubMed]

4. Marchi, S.; Patergnani, S.; Missiroli, S.; Morciano, G.; Rimessi, A.; Wiecknowski, M.; Giorgi, C.; Pinton, P. Mitochondrial and endoplasmic reticulum calcium homeostasis and cell death. Cell Calcium 2018, 69, 62-72. [CrossRef]

5. Rieusset, J. The role of endoplasmic reticulum-mitochondria contact sites in the control of glucose homeostasie: An update. Cell Death Dis. 2018, 9, 388. [CrossRef]

6. Cho, I.; Adelman, G.; Lim, Y.; Marto, J.; Cho, G.; Golden, J. Ascorbate peroxidase proximity labelling coupled with biochemical fractionation identifies promoters of endoplasmic reticulum-mitochondrial contacts. J. Biol. Chem. 2017, 292, 16382-16392. [CrossRef] [PubMed]

7. Hung, V.; Lam, S.; Udeshi, N.; Svinkina, T.; Guzman, G.; Mootha, V.; Carr, S.; Ting, A. Proteomic mapping of cytosol-facing outer mitochondrial and ER membranes in living human cells by proximity biotinylation. Elife 2017, 6, e24463. [CrossRef]

8. Booth, D.; Enyedi, B.; Geiszt, M.; Varnai, P.; Hajnoczky, G. Redox nanodomains are induced by and control calcium signaling at the ER-mitochondrial interface. Mol. Cell 2016, 63, 240-248. [CrossRef]

9. Rasmussen, N. Mitochondrial structure and the practice of cell biology in the 1950s. J. Hist. Biol. 1995, 28, 381-429. [CrossRef]

10. Pagliarini, D.; Rutter, J. Hallmarks of a new era in mitochondrial biochemistry. Genes Dev. 2013, 27, $2615-2627$. [CrossRef]

11. Sjostrand, F.S. Electron microscopy of mitochondria and cytoplasmic double membranes. Nature 1953, 171, 30-32. [CrossRef] [PubMed]

12. Palade, GE. An electron microscope study of the mitochondrial structure. J. Histochem. Cytochem. 1953, 1, 188-211. [CrossRef] [PubMed]

13. Mannella, C. Structure and dynamics of the mitochondrial inner membrane cristae. Biochim. Biophys. Acta 2006, 1763, 542-548. [CrossRef] [PubMed]

14. Zick, M.; Rabl, R.; Reichert, A. Cristae formation-linking ultrastructure and function of mitochondria. Biochim. Biophys. Acta Mol. Cell Res. 2009, 1793, 5-19. [CrossRef]

15. Cogliati, S.; Enriquez, J.; Scorrano, L. Mitochondrial cristae: Where beauty meets functionality. Trends Biochem. Sci. 2016, 41, 261-273. [CrossRef] [PubMed]

16. Baloyannis, S. Mitochondrial alterations in Alzheimer's disease. J. Alzheimers Dis. 2006, 9, 119-126. [CrossRef]

17. Chung, M.; Shu, Y. Ultrastructural changes of mitochondria in the skeletal muscle of patients with amyotrophic lateral sclerosis. Ultrastruct. Pathol. 2002, 26, 3-7. [CrossRef]

18. Beal, M. Mitochondria and neurodegeneration. Novartis Found. Symp. 2007, 287, 183-192.

19. Nielsen, J.; Gejl, K.; Hey-Mogensen, M.; Holmberg, H.; Suetta, C.; Krustrup, P.; Elemans, C.; Ortenblad, N. Plasticity in mitochondrial cristae density allows metabolic capacity modulation in human skeletal muscle. J. Physiol. 2017, 595, 2839-2847. [CrossRef]

20. Jimenez, L.; Laporte, D.; Duvezin-Caubet, S.; Courtout, F.; Sagot, I. Mitochondrial ATP synthase cluster as discrete domains that reorganize with the cellular demand for oxidative phosphorylation. J. Cell. Sci. 2014, 127, 719-726. [CrossRef]

21. Scorrano, L.; Ashiya, M.; Buttle, K.; Weiler, S.; Oakes, S.; Mannella, C.; Korsmeyer, S. A distinct pathway remodels mitochondrial cristae and mobilizes cytochrome c during apoptosis. Dev. Cell 2002, 2, 55-67. [CrossRef]

22. Stacchiotti, A.; Favero, G.; Giugno, L.; Golic, I.; Korac, A.; Rezzani, R. Melatonin efficacy in obese leptin-deficient mice heart. Nutrients 2017, 9, 1323. [CrossRef] [PubMed]

23. Stacchiotti, A.; Favero, G.; Giugno, L.; Lavazza, A.; Reiter, R.; Rodella, L.; Rezzani, R. Mitochondrial and metabolic dysfunction in renal convoluted tubules of obese mice: Protective role of melatonin. PLoS ONE 2014, 9, e111141. [CrossRef] [PubMed] 
24. Collins, T.; Berridge, M.; Lipp, P.; Bootman, M. Mitochondria are morphologically and functionally heterogeneous within cells. EMBO J. 2002, 21, 1616-1627. [CrossRef]

25. Yoon, Y.; Galloway, C.; Jhen, B.; Yu, T. Mitochondrial dynamics in diabetes. Antioxid. Redox Signal. 2011, 14, 439-457. [CrossRef] [PubMed]

26. Galloway, C.; Lee, H.; Yoon, Y. Mitochondrial morphology-emerging role in bioenergetics. Free Radic. Biol. Med. 2012, 53, 2218-2228. [CrossRef]

27. Youle, R.; Van der Bliek, A. Mitochondrial fission, fusion, and stress. Science 2012, 337, 1062-1065. [CrossRef]

28. Varanita, T.; Soriano, M.; Romanello, V.; Zaglia, T.; Quintana-Cabrera, R.; Semenzato, M.; Menabò, R.; Costa, V.; Civiletto, G.; Pesce, P.; et al. The OPA1-dependent mitochondrial cristae remodeling pathway controls atrophic, apoptotic, and ischemic tissue damage. Cell Metab. 2015, 21, 834-844. [CrossRef]

29. Wells, W. Ribosomes, or the particles of Palade. J. Cell. Biol. 2005, 168, 12. [CrossRef]

30. Palade, G.; Porter, K. Studies on the endoplasmic reticulum. I. Its identification in cells in situ. J. Exp. Med. 1954, 100, 641-656.

31. Federovitch, C.; Rou, D.; Hampton, R. The dynamic ER: Experimental approaches and current questions. Curr. Opin. Cell Biol. 2005, 17, 409-414. [CrossRef] [PubMed]

32. Borgese, N.; Francolini, M.; Snapp, E. Endoplasmic reticulum architecture: Structure in flux. Curr. Opin. Cell Biol. 2006, 18, 358-364. [CrossRef] [PubMed]

33. Fossati, M.; Borgese, N.; Colombo, S.; Francolini, M. Visualization of endoplasmic reticulum subdomains in cultured cells. J. Vis. Exp. 2014, 84, 50985. [CrossRef] [PubMed]

34. Fasana, E.; Fossati, M.; Ruggiano, A.; Brambillasca, S.; Hoogenraad, C.; Navone, F.; Francolini, M.; Borgese, N. A VAPB mutant linked to amyotrophic lateral sclerosis generates a novel form of organized smooth endoplasmic reticulum. FASEB J. 2010, 24, 1419-1430. [CrossRef] [PubMed]

35. Schwarz, D.; Blower, M. The endoplasmic reticulum: Structure, function and response to cellular signalling. Cell. Mol. Life Sci. 2016, 73, 79-84. [CrossRef] [PubMed]

36. Chavez-Valdez, R.; Flock, D.; Martin, L.; Northington, F. Endoplasmic reticulum pathology and stress response in neurons precede programmed necrosis after neonatal hypoxia-ischemia. Int. J. Dev. Neurosci. 2016, 48, 58-70. [CrossRef] [PubMed]

37. Rowland, A.; Voeltz, G. Endoplasmic reticulum-mitochondria contacts: Function of the junction. Nat. Rev. Mol. Cell. Biol. 2012, 13, 607-625. [CrossRef]

38. English, A.; Voeltz, G. Endoplasmic reticulum structure and interconnections with other organelles. Cold Spring Harb. Perspect. Biol. 2013, 5, a013227. [CrossRef]

39. Cohen, S.; Valen, A.; Lippincott-Schwartz, J. Interacting organelles. Curr. Opin. Cell Biol. 2018, 53, 84-91. [CrossRef]

40. Csordas, G.; Renken, C.; Varnai, P.; Walter, L.; Weaver, D.; Buttle, K.; Balla, T.; Mannella, C.; Hajnoczky, G. Structural and functional features and significance of the physical linkage between ER and mitochondria. J. Cell Biol. 2006, 174, 915-921. [CrossRef]

41. Csordas, G.; Hainoczky, G. SR/ER-mitochondrial local communication: Calcium and ROS. Biochim. Biophys. Acta 2009, 1787, 1352-1362. [CrossRef] [PubMed]

42. Friedman, J.; Lackner, L.; West, M.; Di Benedetto, J.; Nunnari, J.; Voeltz, G. ER tubules mark sites of mitochondrial division. Science 2011, 334, 358-362. [CrossRef] [PubMed]

43. Giacomello, M.; Pellegrini, L. The coming of age of the mitochondria-ER contact: A matter of thickness. Cell Death Differ. 2016, 23, 1417-1427. [CrossRef]

44. Wu, H.; Carvalho, P.; Voeltz, G. Here, there, and everywhere: The importance of ER membrane contact sites. Science 2018, 361. [CrossRef] [PubMed]

45. Raturi, A.; Simmen, T. Where the endoplasmic reticulum and the mitochondrion tie the knot: The mitochondria-associated membrane (MAM). Biochim. Biophys. Acta 2013, 1833, 213-224. [CrossRef] [PubMed]

46. Vance, J. MAM (mitochondria-associated membranes) in mammalian cells: Lipids and beyond. Biochim. Biophys. Acta 2014, 1841, 595-609. [CrossRef] [PubMed]

47. Giorgi, C.; Missiroli, S.; Patergnani, S.; Duszynski, J.; Wieckowski, M.; Pinton, P. Mitochondria-associated membranes: Composition, molecular mechanisms, and pathophysiological implications. Antioxid. Redox Signal. 2015, 22, 995-1019. [CrossRef]

48. Kornmann, B.; Walter, P. ERMES-mediated ER-mitochondria contacts: Molecular hubs for the regulation of mitochondrial biology. J. Cell Sci. 2010, 123, 1389-1393. [CrossRef] 
49. Kornmann, B.; Currie, E.; Collins, S.; Schuldiner, M.; Nunnari, J.; Weissman, J.; Walter, P. An ER-mitochondria tethering complex revealed by a synthetic biology screen. Science 2009, 325, 477-481. [CrossRef]

50. Scharwey, M.; Tatsuta, T.; Langer, T. Mitochondrial lipid transport at a glance. J. Cell Sci. 2013, 126, 5317-5323. [CrossRef]

51. Flis, V.; Daum, G. Lipid transport between the endoplasmic reticulum and mitochondria. Cold Spring Harb. Perspect. Biol. 2013, 5, a013235. [CrossRef] [PubMed]

52. Tasseva, G.; Bai, H.; Davidescu, M.; Haromy, A.; Michelakis, E.; Vance, J. Phosphatidylethanolamine deficiency in mammalian mitochondria impairs oxidative phosphorylation and alters mitochondrial morphology. J. Biol. Chem. 2013, 288, 4158-4173. [CrossRef] [PubMed]

53. Rockenfeller, P.; Koska, M.; Pietrocola, F.; Minois, N.; Knittelfelder, O.; Sica, V.; Franz, J.; Carmona-Gutierrez, D.; Kroemer, G.; Madeo, F. Phosphatidylethanolamine positively regulates autophagy and longevity. Cell Death Differ. 2015, 22, 499-508. [CrossRef] [PubMed]

54. Hamasaki, M.; Furuta, N.; Matsuda, A.; Nezu, A.; Yamamoto, A.; Fujita, N.; Ooomori, I.; Noda, T.; Haraguchi, T.; Hiraoka, Y. Autophagosomes form at ER-mitochondria contacts site. Nature 2013, 495, 389-393. [CrossRef] [PubMed]

55. Wang, P.; Garcin, P.; Fu, M.; Masoudi, M.; St-Pierre, P.; Panté, N.; Nabi, I. Distinct mechanisms controlling rough and smooth endoplasmic reticulum contacts with mitochondria. J. Cell Sci. 2015, 128, 2759-2765. [CrossRef]

56. Sood, A.; Jeyaraju, V.; Prudent, J.; Caron, A.; Lemieux, P.; McBride, H.; Laplante, M.; Toth, K.; Pellegrini, L. A mitofusin-2-dependent inactivating cleavage of Opa 1 links changes in mitochondria cristae and ER contacts in the postprandial liver. Proc. Natl. Acad. Sci. USA 2014, 111, 16017-16022. [CrossRef] [PubMed]

57. Rizzuto, R.; Pinton, P.; Carrington, W.; Fay, F.; Fogarty, K.; Lifshitz, L.; Tuft, R.; Pozzan, T. Close contacts with the endoplasmic reticulum as determinants of mitochondrial $\mathrm{Ca}^{2+}$ responses. Science 1998, 280, 1763-1766. [CrossRef] [PubMed]

58. Bravo, R.; Vicencio, J.; Parra, V.; Troncoso, F.; Munoz, J.; Bui, M.; Quiroga, C.; Rodriguez, A.; Verdejo, H.; Ferreira, J.; et al. Increased ER-mitochondrial coupling promotes mitochondrial respiration and bioenergetics during early phases of ER stress. J. Cell Sci. 2011, 124, 2143-2152. [CrossRef]

59. Arruda, P.; Pers, B.; Parlakgül, G.; Güney, E.; Inouye, K.; Hotamisligil, G. Chronic enrichment of hepatic endoplasmic reticulum-mitochondria contact leads to mitochondrial dysfunction in obesity. Nat. Med. 2014, 20, 1427-1435. [CrossRef]

60. Stacchiotti, A.; Favero, G.; Lavazza, A.; Golic, I.; Aleksic, M.; Korac, A.; Rodella, L.; Rezzani, R. Hepatic macrosteatosis is partially converted to microsteatosis by melatonin supplementation in $o b / o b$ mice non-alcoholic fatty liver disease. PLoS ONE 2016, 11, e0148115. [CrossRef]

61. Tang, B. Sirt1 and the mitochondria. Mol. Cells 2016, 39, 87-95. [CrossRef] [PubMed]

62. Tubbs, E.; Theurey, P.; Vial, G.; Bendridi, N.; Bravard, A.; Chavin, M.; Ti-Cao, J.; Zoulim, F.; Bartosch, B.; Ovize, M.; et al. Mitochondria-associated endoplasmic reticulum membrane (MAM) integrity is required for insulin signaling and is implicated in hepatic insulin resistance. Diabetes 2014, 63, 3279-3294. [CrossRef] [PubMed]

63. Paillusson, S.; Stoica, R.; Gomez-Suaga, P.; Lau, D.; Mueller, S.; Miller, T.; Miller, C. There's something wrong in my MAM; the ER-mitochondria axis and neurodegenerative diseases. Trends Neuros. 2016, 39, 146-157. [CrossRef] [PubMed]

64. Wu, Y.; Whiteus, C.; Xu, S.; Hayworth, K.; Weinberg, R.; Hess, H.; De Camilli, P. Contacts between the endoplasmic reticulum and other membrane in neurons. PNAS 2017, 114, E4859-E4867. [CrossRef] [PubMed]

65. Csordas, G.; Várnai, P.; Golenár, T.; Roy, S.; Purkins, G.; Schneider, T.; Balla, T.; Hajnóczky, G. Imaging interorganelle contacts and local calcium dynamics at the ER-mitochondrial interface. Mol. Cell 2010, 39, 121-132. [CrossRef] [PubMed]

66. Elgass, K.; Smith, E.; Le Gros, M.; Larabell, C.; Ryan, M. Analysis of ER-mitochondria contacts using correlative fluorescent microscopy and soft $X$ ray tomography of mammalian cells. J. Cell Sci. 2015, 128, 2795-2804. [CrossRef] [PubMed]

67. Harmon, M.; Larkman, P.; Hardingham, G.; Jackson, M.; Skehel, P. A Bi-fluorescence complementation system to detect associations between the endoplasmic reticulum and mitochondria. Sci. Rep. 2017, 7, 174-167. [CrossRef] 
68. Naon, D.; Zaninello, M.; Giacomello, M.; Varanita, T.; Grespi, F.; Lakshminaranayan, S.; Serafini, A.; Semenzato, M.; Herkenne, S.; Hernandez-Alvarez, M.; et al. Critical reappraisal confirms that mitofusin 2 is an endoplasmic reticulum-mitochondria tether. PNAS 2016, 113, 11249-11254. [CrossRef]

69. Galmes, R.; Houcine, A.; Van Vlieta, A.; Agostinis, P.; Jackson, C.; Giordano, F. ORP5/ORP8 localize to endoplasmic reticulum-mitochondria contacts and are involved in mitochondrial function. EMBO Rep. 2016, 17, 800-810. [CrossRef]

70. Cieri, D.; Vicario, M.; Giacomello, M.; Vallese, F.; Filadi, R.; Wagner, T.; Pozzan, T.; Pizzo, P.; Scorrano, L.; Brini, M.; et al. SPLICS: A split green fluorescent protein-based contact site sensor for narrow and wide heterotypic organelle juxtaposition. Cell Death Differ. 2018, 25, 1131-1145. [CrossRef]

71. Theurey, P.; Tubbs, E.; Vial, G.; Jacquemetton, J.; Bendridi, N.; Chauvin, M.; Alam, M.; Le Romancer, M.; Vidal, H.; Rieusset, J. Mitochondria-associated endoplasmic reticulum membranes allow adaptation of mitochondrial metabolism to glucose availability in the liver. J. Mol. Cell Biol. 2016, 8, 129-143. [CrossRef] [PubMed]

72. Rieusset, J.; Fauconnier, J.; Paillard, M.; Belaidi, E.; Tubbs, E.; Chauvin, A.; Durand, A.; Bravard, A.; Teixeira, G.; Bartosch, B.; et al. Disruption of calcium transfer from ER to mitochondria links alterations of mitochondria-associated ER membrane integrity to hepatic insulin resistance. Diabetologia 2016, 59, 614-623. [CrossRef] [PubMed]

73. Holcman, D.; Parutto, P.; Chambers, J.; Fantham, M.; Young, L.; Marciniak, S.; Kaminski, C.; Ron, D.; Avezov, E. Single particle trajectories reveal active endoplasmic reticulum luminal flow. Nature Cell Biol. 2018, 20, 1118-1125. [CrossRef] [PubMed]

74. Erpazoglou, Z.; Mouton-Liger, F.; Corti, O. From dysfunctional endoplasmic reticulum mitochondria coupling to neurodegeneration. Neurochem. Int. 2017, 109, 171-183. [CrossRef] [PubMed]

75. Angebault, C.; Fauconnier, J.; Patergnani, S.; Rieusset, J.; Danese, A.; Affortit, C.; Jagodzinska, J.; Megy, C.; Quiles, M.; Cazevielle, C.; et al. ER-mitochondria cross talk is regulated by the $\mathrm{Ca}^{2+}$ sensor NCS1 and is impaired in Wolfram syndrome. Sci. Signal. 2018, 11, 1380. [CrossRef] [PubMed]

(C) 2018 by the authors. Licensee MDPI, Basel, Switzerland. This article is an open access article distributed under the terms and conditions of the Creative Commons Attribution (CC BY) license (http:/ / creativecommons.org/licenses/by/4.0/). 